\title{
Foreign Relations in Brazilian Federal Units: An Analysis of Expenditures and Political Parties
}

Relações Exteriores nos Estados da Federação Brasileiros: Uma Análise de Gastos e Partidos Políticos

Ricardo Margalho Prins ${ }^{1}$

\begin{abstract}
Through analysis of official documents, this paper addresses the field of International Relations of subnational entities. It aims to verify the following hypothesis, proposed in the conclusion of a well-known article in the area: Is the external action of subnational governments in Brazil more intense in federal units where the dominant political coalition matches the dominant political coalition in the central government?
\end{abstract}

Keywords: Paradiplomacy; Political Parties; Subnational Governments.

\section{RESUMO}

Por meio de análise de documentos oficiais, este paper versa dentro do campo das relações internacionais de entes subnacionais. $O$ presente trabalho visa verificar a hipótese a seguir, proposta em um artigo bastante conhecido na área: é a atuação externa de governos subnacionais no Brasil mais intensa em unidades nas quais há coalizões políticas dominantes correspondentes àquelas dominantes no governo central?

Palavras-chave: Paradiplomacia; Partidos Políticos; Governos Subnacionais.

\section{TEXT INTRODUCTION}

The "growing academic interest" for the research of the external role of subnational governments (SALOMON; NUNES, 2007) is complemented by the increase of the foreign relations activities done by the Brazilian subnational governments (PRAZERES, 2004). In the last 20 years, activities such as the ones aforementioned can be observed in Rio Grande do Sul (SALOMON; NUNES, 2007), São Paulo and Bahia

1 Graduando em Relações Internacionais no Centro Universitário Internacional. Pesquisador no NEPRI/UFPR - Núcleo de Pesquisa em Relações Internacionais. Curitiba, PR, Brasil.

Conjuntura Global, Vol. 4, n. 1, jan./abr., 2015, p. 39-46. 
(ALMEIDA, 2012), for example. Although these activities are a reality, there are a certain degree of questioning regarding its legitimacy (RODRIGUES, 2008).

This paper aims to discuss the hypothesis suggested in the article written by Salomon and Nunes, which states that "both in structures, procedures and in substance, the foreign activities" (SALOMON; NUNES, 2007, p. 140) of a subnational government [in Brazil] is related to the central government. Thus, the matter is addressed here considering that there is a greater degree of foreign relations activity in the subnational units in which the dominant political coalition matches the dominant political coalition in the central government.

The verification of the hypothesis will be attained through an analysis of the expenditures declared by the Brazilian subnational federal states (estados) found in the Brazilian National Treasure Office (Secretaria do Tesouro Nacional), from 1995 to 2012, thus covering a period with two distinct dominant political coalitions in the country. Hence, a qualitative analysis of the quantitative data found, along with information about the dominant political parties in the Brazilian subnational states in that period will be performed.

Since this research is still halfway through in its elaboration process, the conclusions are yet to be presented. Hence, the discussion here will but present useful data that will allow partially conclusions to be extracted and reached in this moment.

\section{Paradiplomacy in Brazil}

The analysis about the foreign activities done by non-central or subnational governments, are very diverse. They are related to the Development Theory - more precisely, to the Endogenous Development Theory - dealing with both the concept of development and with paradiplomacy (ALMEIDA, 2012).

What is the nature of these foreign activities? Mônica Salomon and Carmen Nunes discussed the matter in their article, summarizing many research documents about this topic that bring concepts and terms such as "paradiplomacy", "constituent 
units diplomacy", "federative diplomacy", among many others used in various attempts to analyze the phenomenon (SALOMON; NUNES, 2007).

It is accepted, for this particular paper, the definition of paradiplomacy presented by Soldatos (1990), which states that paradiplomatic activities are the ones that comprise international relations of non-central governments. It has to be acknowledged here that the conceptual discussions about this matter is broadly present in other academic works, as for example the articles that deal with the differentiation between Paradiplomacy and Decentralized Cooperation, by distinguishing the actors involved in the foreign activities of non-central governments (CEZÁRIO; ANDRADE, 2008).

Another research field regarding Paradiplomacy is about the determinant factors for its activities. Soldatos (1990) analyzes the determinant factors for the existence of paradiplomatic activities in three levels: local, federal and external. In Brazilian literature, there are works such as Matsumoto (2011) and Gomes Filho (2011), that present interesting discussions about the possible determinant factors for paradiplomacy.

Some of the common determinant factors found among the literature about the issue are the weakening of the Nation-State; the globalization process and the changes in the international system derived from it; political needs; economical needs; inefficiency of national policies, and some other factors. Nothing in the literature found specifies details about determinant factor hierarchy or relevance, or none of the specified determinant factors are presented as fundamental.

The brilliant conclusion of the article by Salomon and Nunes about the paradiplomatic activity in Rio Grande do Sul offers an additional hypothesis to be verified: both in structures, procedures and in substance, the foreign activities" (SALOMON; NUNES, 2007, p. 140) of a subnational government [in Brazil] is related to the central government. Thus, the matter is addressed here considering that there is a greater degree of foreign relations activity in the subnational units in which the dominant political coalition matches the dominant political coalition in the central government. 
Hence, we will work in the issue presented through the hypothesis above by means of data analysis from subnational Brazilian state's expenditures and political parties information for the dominant coalition groups in each one of the states that have reportedly participated in foreign activities in the 1995-2012 period.

\section{Preliminary data analysis}

From the data archives of the Brazilian National Treasury Office (Secretaria do Tesouro Nacional), financial reports regarding expenditures from each of the subnational Brazilian states can be found. The expenditures analyzed were those reported as Foreign Relations (Relações Exteriores). A profound analysis of the data below is yet to be made, which gives room for questions such as if there were other foreign relation activities performed by states that had their expenses declared under a different category.

We acknowledge that there are states which didn't declare any expenses under Foreign Relations and that even so have widely known paradiplomatic (or decentralized cooperation) activities - such as Rio de Janeiro for example. Hence, it is worth mentioning that there is no expressed attempt in here to assume more than a possible correlation between political identity between the leading coalitions in local and central governments and the subnational foreign relations activity.

The table below summarizes all expenses between 1995 and 2012, declared under the Foreign Relations category. A few observations have to be made though: the year 2001 does not display the Foreign Relations category; no states have declared expenses in the year 1995; all the states that did not declare expenses in the Foreign Relations are missing from the table:

Table 1 - Subnational Brazilian States expenses with Foreign Relations 1 (BRASIL, 2014)

\begin{tabular}{l|ll|ll|ll|ll} 
& \multicolumn{2}{|c|}{ BA } & \multicolumn{2}{c|}{ GO } & \multicolumn{2}{c|}{ MG } & PI \\
\hline 2004 & $\mathrm{R} \$$ & - & $\mathrm{R} \$$ & $2.088 .266,32$ & $\mathrm{R} \$$ & & $\mathrm{R} \$$
\end{tabular}




\begin{tabular}{l|cr|cr|rr|rr}
2005 & $\mathrm{R} \$$ & - & $\mathrm{R} \$$ & $370.880,00$ & $\mathrm{R} \$$ & $3.315 .826,43$ & $\mathrm{R} \$$ & - \\
2006 & $\mathrm{R} \$$ & - & $\mathrm{R} \$$ & $103.921,55$ & $\mathrm{R} \$$ & $26.198 .588,54$ & $\mathrm{R} \$$ & - \\
2007 & $\mathrm{R} \$$ & - & $\mathrm{R} \$$ & $1.200,00$ & $\mathrm{R} \$$ & $350.297,17$ & $\mathrm{R} \$$ & - \\
2008 & $\mathrm{R} \$$ & - & $\mathrm{R} \$$ & $1.011,03$ & $\mathrm{R} \$$ & $631.968,71$ & $\mathrm{R} \$$ & - \\
2009 & $\mathrm{R} \$$ & $161.068,94$ & $\mathrm{R} \$$ & - & $\mathrm{R} \$$ & $747.804,27$ & $\mathrm{R} \$$ & $112.050,24$ \\
2010 & $\mathrm{R} \$$ & $30.082,66$ & $\mathrm{R} \$$ & $459.655,70$ & $\mathrm{R} \$$ & $722.190,32$ & $\mathrm{R} \$$ & 320,00 \\
2011 & $\mathrm{R} \$$ & - & $\mathrm{R} \$$ & $90.469,31$ & $\mathrm{R} \$$ & $91.730,97$ & $\mathrm{R} \$$ & - \\
2012 & $\mathrm{R} \$$ & $37.310,21$ & $\mathrm{R} \$$ & - & $\mathrm{R} \$$ & $56.220,07$ & $\mathrm{R} \$$ & -
\end{tabular}

Source: Secretaria do Tesouro Nacional - STN (Brazilian National Treasure Office) 
Table 2 - Subnational Brazilian States expenses with Foreign Relations 2 (BRASIL, 2014)

\begin{tabular}{|c|c|c|c|c|c|c|c|c|}
\hline & \multicolumn{2}{|r|}{ PR } & \multicolumn{2}{|c|}{$\mathrm{RR}$} & \multicolumn{2}{|c|}{ RS } & \multicolumn{2}{|r|}{ SC } \\
\hline 1996 & $\mathrm{R} \$$ & - & $\mathrm{R} \$$ & - & $\mathrm{R} \$$ & $227.647,40$ & $\mathrm{R} \$$ & - \\
\hline 1997 & $\mathrm{R} \$$ & - & $\mathrm{R} \$$ & - & $\mathrm{R} \$$ & $780.068,66$ & $\mathrm{R} \$$ & - \\
\hline 1998 & $\mathrm{R} \$$ & - & $\mathrm{R} \$$ & - & $\mathrm{R} \$$ & $621.941,16$ & $\mathrm{R} \$$ & - \\
\hline 1999 & $\mathrm{R} \$$ & - & $\mathrm{R} \$$ & - & $\mathrm{R} \$$ & $378.609,73$ & $\mathrm{R} \$$ & - \\
\hline 2000 & $\mathrm{R} \$$ & - & $\mathrm{R} \$$ & - & $\mathrm{R} \$$ & $108.022,45$ & $\mathrm{R} \$$ & - \\
\hline 2002 & $\mathrm{R} \$$ & - & $\mathrm{R} \$$ & - & $\mathrm{R} \$$ & $201.161,35$ & $\mathrm{R} \$$ & - \\
\hline 2003 & $\mathrm{R} \$$ & - & $\mathrm{R} \$$ & - & $\mathrm{R} \$$ & $207.808,31$ & $\mathrm{R} \$$ & - \\
\hline 2004 & $\mathrm{R} \$$ & - & $\mathrm{R} \$$ & $105.186,10$ & $\mathrm{R} \$$ & $3.325,07$ & $\mathrm{R} \$$ & - \\
\hline 2005 & $\mathrm{R} \$$ & - & $\mathrm{R} \$$ & & $\mathrm{R} \$$ & $4.813,36$ & $\mathrm{R} \$$ & - \\
\hline 2006 & $\mathrm{R} \$$ & - & $\mathrm{R} \$$ & - & $\mathrm{R} \$$ & $4.570,97$ & $\mathrm{R} \$$ & - \\
\hline 2008 & $\mathrm{R} \$$ & - & $\mathrm{R} \$$ & - & $\mathrm{R} \$$ & $24.689,28$ & $\mathrm{R} \$$ & $1.264 .192,04$ \\
\hline 2009 & $\mathrm{R} \$$ & - & $\mathrm{R} \$$ & - & $\mathrm{R} \$$ & $42.117,95$ & $\mathrm{R} \$$ & $1.394 .143,31$ \\
\hline 2010 & $\mathrm{R} \$$ & - & $\mathrm{R} \$$ & - & $\mathrm{R} \$$ & $34.847,00$ & $\mathrm{R} \$$ & $1.447 .508,01$ \\
\hline 2011 & $\mathrm{R} \$$ & - & $\mathrm{R} \$$ & - & $\mathrm{R} \$$ & $11.273,20$ & $\mathrm{R} \$$ & $2.860 .664,45$ \\
\hline 2012 & $\mathrm{R} \$$ & $1.325 .143,79$ & $\mathrm{R} \$$ & - & $\mathrm{R} \$$ & & $\mathrm{R} \$$ & - \\
\hline
\end{tabular}

Source: Secretaria do Tesouro Nacional -STN (Brazilian National Treasure Office)

A preliminary reading shows that only three states have regular expenses in Foreign Relations: Rio Grande do Sul (RS), Goias (GO) and Minas Gerais (MG). The other five states with declared expenses are Paraná (PR), Roraima (RR), Santa Catarina (SC), Bahia (BA) and Piauí (PI). All other states as mentioned before have no declared expenses; hence will not be considered for our preliminary analysis.

The table below will display the political parties that were dominant in the eight states above. The political party displayed will be the governor's party. This choice was made considering that the parties analyzed for the Brazilian central government are the President's. The data for the table was gathered from several sources, the resulting table is available on request, and it contains data from all Brazilian states from 1995 to 2012.

Table 2: Dominant political parties per state and period, Brazil.

\begin{tabular}{c|c|c|c|c|c|c|c|c} 
& BA & GO & MG & PI & PR & RR & RS & SC \\
\hline $1995-1999$ & PFL & PMDB & PSDB & PMDB & PDT & PTB & PMDB & PMDB \\
\hline $1999-2003$ & PFL/PL & PSDB & PMDB & PMDB/PFL & PFL & PTB/PT & PT & PP \\
\hline $2003-2007$ & PFL & PSDB/PP & PSDB & PT & PMDB & PT/PTB & PMDB & PMDB \\
\hline $2007-2011$ & PT & PP & PSDB & PT/PSB & PMDB & PSDB & PSDB & PMDB \\
\hline $2011-2012$ & PT & PSDB & PSDB & PSB & PSDB & PSDB & PT & DEM
\end{tabular}

Source: Personal database 
Considering that during the 1995-2003 period, the dominant political coalition was from PSDB party and that PT was the dominant coalition from 2003-2012, the following preliminary conclusions can be inferred from the data presented above. First, from observing the RS state leadership in the period 1995-2003, the fact that there was divergence between the dominant political parties in local and central governments did not present itself as an impeding factor for foreign relations activities. Similar conclusions can be extracted from observing GO in the 2003-2011 period and MG in the 2005-2012 period.

Unfortunately, the present paper acknowledges that there is still much to be observed in order to present a secure conclusion regarding the matter, from the analyzed data - it will be done in a future moment. Regardless of that awareness, it can be easily said that the hypothesis presented by Salomon and Nunes (SALOMON; NUNES, 2007, p. 140) at the conclusion of their work, is not valid when verified empirically.

\section{REFERENCES}

ALMEIDA, J. Paradiplomacia no Brasil: uma análise sobre o fenômeno em Salvador e São Paulo. In: 1o Seminário Nacional de Pós-Graduação em Relações Internacionais. Anais...Brasília, 2012.

BRASIL. Estados $\quad$ e $\quad$ municípios. Disponível em http://www3.tesouro.fazenda.gov.br/estados municipios/. Brasília, 2014.

CEZÁRIO, G.; ANDRADE, M. A cooperação descentralizada no Brasil. 2008. Disponível em

http://www.gustavocezario.com.br/gustavocezario/Publicacoes files/A\%20cooperac\% CC\%A7a\%CC\%83o\%20descentralizada\%20no\%20Brasil.pdf. Acesso em 22/08/2014.

GOMES FILHO, F.A paradiplomacia subnacional no Brasil: uma análise da política de atuação internacional dos governos estaduais fronteiriços da Amazônia. 2011. 276 f. Tese (Doutorado em Relações Internacionais e Desenvolvimento Regional) Curso de Pós-graduação em Relações Internacionais, Universidade de Brasília, Brasília.

MATSUMOTO, C. As determinantes locais da paradiplomacia: o caso dos municípios brasileiros. 2011. 276 f. Dissertação (Mestrado em Relações Internacionais) - Curso de Pós-graduação em Relações Internacionais, Universidade de Brasília, Brasília.

PRAZERES, Tatiana. Por uma atuação constitucionalmente viável das unidades federadas brasileiras ante os processos de integração regional. In: VIGEVANI, Tullo; Conjuntura Global, Vol. 4, n. 1, jan./abr., 2015, p. 39-46. 
WANDERLEY, Luiz Eduardo; BARRETO, M. Inês e MARIANO, P. (orgs). A dimensão subnacional e as relações internacionais. São Paulo: EDUC; UNESP/EDUSC, 2004, p. 283-312.

RODRIGUES, G. Relações internacionais federativas no Brasil. In: Dados - Revista de Ciências Sociais, vol. 51, no 4, 2008, p. 1015-1034. Rio de Janeiro, 2008.

SALOMON, M.; NUNES, C. A ação externa dos governos subnacionais no Brasil: os casos do Rio Grande do Sul e de Porto Alegre. Um estudo comparativo de dois tipos de atores mistos. In: Contexto Internacional, vol. 29, no 1, jan/jun. 2007, p. 99-147. Rio de Janeiro, 2007.

SOLDATOS, P., An Explanatory Framework for the Study of Federated States as Foreign policy Actors, In: MICHELMANN, J. y SOLDATOS, P., Federalism and International Relations: The Role of Subnational Units, Oxford: Clarendon Press, 1990. 